\title{
Original Paper / Artigo Original Special offer while stocks last: high-energy pulse of nectar caused by a massive post-fire flowering of Sinningia elatior (Gesneriaceae) in an area of Cerrado and implications for its pollination
}

\author{
Francielle Paulina de Araújo ${ }^{1,3}$ \& Léo Correia da Rocha-Filho ${ }^{2}$
}

\begin{abstract}
The massive post-fire flowering of Sinningia elatior (Gesneriaceae) was examined in an area of Cerrado (Brazilian savanna). To study the reproductive system, pollination tests were conducted in the field. Individuals of $S$. elatior were found isolated or grouped in the area, the orange to reddish flowers are odorless and tubular. Despite being a protandrous species, $S$. elatior is self-compatible with spontaneous self-pollination, without apomixis. The male phase lasted two days whereas the female lasted three days. The caloric reward per flower was estimated in $40.8 \mathrm{cal} \pm 4.2(\mathrm{n}=20)$. The massive post-fire flowering of this species provided a large, episodic supply of nectar to nine hummingbirds' species and 16 insects' species. While all hummingbirds acted as pollinators, insects were only recorded as nectar/pollen thieves. The S. elatior population offered around $23 \mathrm{Kcal}$, supplying the energetic needs of approximately two to four hummingbirds per day. Postfire massive flowering is rare and unpredictable in the Cerrado. Therefore, the fire regime acts shaping the flowering dynamics of some species, producing mosaics of temporary special offers of floral resources that affect not only the foraging dynamics of pollinators but also the crossing patterns of the plant species.

Key words: Colibri serrirostris, Eupetomena macroura, hummingbirds, nectar, palm swamp.

\section{Resumo}

A intensa floração pós-fogo de Sinningia elatior (Gesneriaceae) foi estudada em uma área de Cerrado. Para estudar o sistema reprodutivo, testes de polinização foram realizados no campo. Espécimes de $S$. elatior foram encontrados isolados ou agrupados na área de estudo, as flores são tubulares, alaranjadas/avermelhadas e desprovidas de odor. Apesar de ser uma espécie protândrica, S. elatior é autocompatível com autopolinização espontânea e não-apomítica. A fase masculina teve duração de dois dias ao passo que a fase feminina durou três dias. A recompensa calórica por flor foi estimada em 40,8 cal $\pm 4,2(\mathrm{n}=20)$. A floração massiva pós-fogo dessa espécie propiciou uma grande e esporádica quantidade de néctar para nove espécies de beija-flores e 16 espécies de insetos. Enquanto todos os beija-flores atuaram como polinizadores, os insetos registrados foram pilhadores de néctar e/ou pólen. A população estudada de $S$. elatior ofereceu cerca de 23 Kcal, suprindo a demanda energética de dois a quatro beija-flores ao longo do dia. Intensas florações pós-fogo são raras e imprevisíveis no Cerrado. Dessa maneira, o regime de fogo atua como um modelador da dinâmica floral de algumas espécies, produzindo mosaicos de ofertas temporárias de recursos florais que afetam não apenas a dinâmica de forrageamento de polinizadores, mas também os padrões de cruzamento das espécies de plantas. Palavras-chave: Colibri serrirostris, Eupetomena macroura, beija-flores, néctar, vereda.
\end{abstract}

\footnotetext{
${ }^{1}$ Universidade Estadual do Rio Grande do Sul, Unidade São Francisco de Paula, R. Assis Brasil 842, Centro, 95400-000, São Francisco de Paula, RS, Brazil.

${ }^{2}$ Universidade de São Paulo, Faculdade de Filosofia, Ciências e Letras de Ribeirão Preto-FFCLRP, Depto. Biologia, Av. Bandeirantes 3900 , Cidade Universitária, 14040-901, Ribeirão Preto, SP, Brazil.

${ }^{3}$ Author for correspondence: franciaralp@yahoo.com.br
} 


\section{Introduction}

Fire is considered one of the major ecological disturbances in several ecosystems that can occur in approximately $70 \%$ of natural area worldwide (Heringer \& Jacques 2001; Neves \& Conceição 2010; Gonçalves et al. 2011; Sherman et al. 2012). Among the natural environments, the Cerrado (Brazilian savanna) is recognized by its high fire incidence, which is one of the main characteristics that mold the phytogeographic domain's landscape (Mistry 1998; Miranda et al. 2002). Hence, many plant species in Cerrado have morphological and physiological adaptations to the fire that include resistance, regeneration and survival strategies (Coutinho 1977; Miranda \& Sato 2005).

The herbaceous flora of Cerrado is very resistant and resilient to fire. Several species exhibit subterranean organs such as rhizomes, bulbs, soboles, and xylopodia that are protected underground (Appezzato-da-Glória 2003). Some of those organs can sprout again rapidly within few days after the fire, with many plant species displaying an intense flowering afterward (Miranda et al. 2002; Miranda \& Sato 2005; Conceição \& Orr 2012; Araújo et al. 2013; Conceição et al. 2013). This high flower production can augment the floral resources availability that leads to an increase in the local abundance of pollinators. Although the massive post-fire flowering has been observed in several species there are no detailed records of plants belonging to the family Gesneriaceae, which encompasses some terrestrial herbs with conspicuous tubers that allow the survival in adverse seasons (Weber et al. 2013). This family is comprised of around 140 genera and 3,500 species distributed predominantly in the tropics (Weber 2004). In Brazil, Araújo et al. (2015) listed 220 recognized species belonging to 28 genera with 37 species of 14 genera occurring in Cerrado. Of that flora, Sinningia Nees is by far the most speciose genus with a total of 72 species and $85 \%$ of endemism (Araújo \& Chautems 2015). Most of the species occur in southeastern Brazil (Perret et al. 2001, 2003; Araújo et al. 2015).

It is estimated that approximately $67 \%$ of Sinningia species are pollinated by hummingbirds (Perret et al. 2001, 2003). The species of subtribe Ligeriineae have features related to hummingbird pollination as campanulate to tubular corollas with coloration that varies from orange to reddish, as well as the presence of nectar and absence of odor, characterizing adaptations attributed to ornithophily (e.g., Ferreira et al. 2016).
Sinningia elatior (Kunth) Chautems is an herb with reddish flowers that bloom from October to March (Chautems 2003; Araújo et al. 2011a). This species is recorded in ecosystems of Amazon, Caatinga, Cerrado, and Atlantic Forest, presenting a wide distribution in Brazil (Araújo \& Chautems 2015). Generally, plant individuals of S. elatior occur scattered in the environment, rarely forming large patches, a feature that hinders the studies on the reproductive biology of this species (FP Araújo, personal communication). In a palm swamp area located in southeastern Brazil, a large population of this species displayed an intense flowering after a natural fire event. In Cerrado, the palm swamp areas are called vereda and consist of plant communities associated with headwaters of streams and Mauritia flexuosa L.f. (Arecaceae) palms. These areas have a unique flora composition but are frequently threatened by fires and cattle grazing. Despite their singularity, little is known about the factors that influence plant reproduction in palm swamps (Araújo et al. 2013).

In light of the above, we aimed to take advantage of this window of opportunity to study a massive post-fire flowering episode. We described the reproductive biology of $S$. elatior as well as evaluated the nectar availability and its floral visitors.

\section{Material and Methods}

Study site

The study was conducted in a palm swamp area on the edge of an island of flooded gallery Forest (Araújo et al. 2011a) at the Ecological Reserve 'Clube de Caça e Pesca Itororó de Uberlândia'

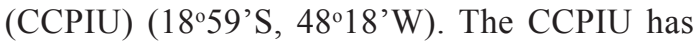
about 400 ha comprised predominantly by cerrado sensu stricto and Mauritia flexuosa palm swamp with two isolated patches of flooded gallery forest (Appolinario \& Schiavini 2002; Ferreira et al. 2016). The reserve is located $8 \mathrm{~km}$ west of the city limits of Uberlândia (18 $\left.8^{\circ} 30^{\prime}-19^{\circ} 30^{\prime} \mathrm{S}, 47^{\circ} 50^{\prime}-48^{\circ} 50^{\prime} \mathrm{W}\right)$, Minas Gerais state, Brazil (Lima et al. 1989).

The regional climate is characterized by a very pronounced seasonality with two well defined seasons: a dry/colder season between April and September and a hot/wet season from October to March. November, December, and January are the most humid period with half of precipitation rates occurring in those months. According to Köppen classification system, the climate is defined as Aw, with higher temperatures in summer (above $35^{\circ} \mathrm{C}$ ) and occasional frosts during the winter (Rosa et al. 1991). 
Fieldwork and laboratory procedures

Fieldwork was carried out between January 2001 and June 2003. Most of the observations were conducted from November 2002 to May 2003, two months after the fire that consumed most part of the herbaceous plant biomass in the study area. Further observations were performed from November 2003 to May 2004 and no other fire event was recorded in the study site. The floral phenology was recorded every two weeks walking a $360 \mathrm{~m}$ trail at the edge of an island of flooded gallery forest. All S. elatior individuals were recorded and the number of open flowers per individual was counted. The flowering pattern of $S$. elatior was described following the classification proposed by Newstrom et al. (1994).

Some data on floral morphology as color, odor, floral rewards, duration of flowers, and changes on reproductive structures were recorded in the field. Flowers preserved in $70 \%$ ethanol were used to characterize the corolla diameter and corolla tube length (from the base to the flower opening). In order to assess the proportion of available flowers in each phenological phase, a total of 424 flowers from 65 individuals were sampled in a single day recording the number of flowers that were in the male or in the female phases.

Nectar production was measured during the morning around 9h00 from 20 flowers bagged previously before opening. Nectar volume was measured using glass micropipettes while sugar concentration was determined with a hand refractometer. The volume and sugar concentration averages were used to estimate the amount of energy in calories per flower. Thus, the values displayed in refractometer in "g sugar/g solution" were converted into "mg sugar/ $\mu$ L nectar" (see Galetto \& Bernadello 2005). It was considered that $1 \mathrm{mg}$ sugar corresponds to 4 calories (Galetto \& Bernadello 2005).

From this data and with the number of flowers sampled in one day, the instantaneous energy of nectar in Kcal that the $S$. elatior population could offer for each sampled day was estimated. On the basis that the daily energetic demand of a hummingbird varies from 6 to $10 \mathrm{Kcal}$ (Carpenter 1983) the number of hummingbirds that this plant population could maintain during its flowering was estimated.

Vouchers of $S$. elatior were collected and dried following the methods described by Fidalgo \& Bononi (1984). They were deposited in 'Herbarium Uberlandense' (HUFU) of the Institute of Biology of the Federal University of Uberlândia under the registration number 33306 .
Reproductive system

To study the reproductive system, pollination tests were conducted in the field. Pre-anthesis flower buds previously bagged were assigned randomly and subjected to one of the five pollination treatments: 1) Hand self-pollination: pollen grains from a given flower was deposited manually on its own stigma $(\mathrm{n}=24)$; 2) Spontaneous self-pollination: floral buds were bagged without any further treatment (n $=43$ ); 3) Emasculation without pollination: floral buds were emasculated and bagged without further treatment $(\mathrm{n}=19)$; 4) Cross-pollination: flowers were emasculated previously in pre-anthesis phase and further pollinated using pollen grains from flowers from other individuals distant at least $30 \mathrm{~m}$ $(n=39)$ and 5) Control: flowers were marked and monitored during flowering until the fruit set $(\mathrm{n}=$ 70). For all treatments, fruit set was considered as pollination success. A Chi-square test $(\mathrm{P}<0.05)$ with Bonferroni correction for pairwise comparisons was used to compare the fruit set percentages resulting from the five distinct pollination treatments.

Stigma receptivity was studied in the field considering the morphological changes during the floral anthesis such as color alterations (Dafni et al. 2005) and the expansion of stigmatic lobules (Kearns \& Inouye 1993).

Pollen viability was determined using the method of cytoplasmic coloration through 10\% acetic-carmine technique in pre-anthesis floral buds fixed in $70 \%$ ethanol, by counting the viable and non-viable pollen grains with a hand counter (Radford et al. 1974).

\section{Floral visitors and pollinators}

Focal observations were performed between $7 \mathrm{~h} 30$ and $15 \mathrm{~h} 30$ in continuous sessions of $3 \mathrm{~h}$ to record the floral visitors and pollinators of $S$. elatior (42h in total). The hummingbirds were observed with binoculars and identified based on descriptions and keys provided by Grantsau (1989). The insects recorded in $S$. elatior flowers were observed regarding their foraging behavior, collected with entomological net and identified in the laboratory. The floral visitors were considered as pollinators when they contacted anthers and stigmatic surfaces.

\section{Results}

Sinningia elatior had annual flowering with only one cycle per year and its blooming period extended ca. 7 months from November 2002 to May 2003. Only one flowering $S$. elatior specimen was recorded with three flowers in December 2001 and 
two flowers in January 2002, a period prior to the fire. In 2002, the flowering occurred in November, one month after the fire recorded at the study site. The flowering peaked in February 2003 and lasted until May (Fig. 1). The subsequent flowering of November 2003 was less intense, with few records of blooming individuals, and occurred without the incidence of fire in the study site.

This plant species is an herb of $0.6-1.0 \mathrm{~m}$ high with cymes that produce one to ten flowers that open one at a time (Fig. 2a) and last up to five days each. Flowers are odorless, hermaphrodite, orange to reddish, tubular with protandry. The male phase lasts two days and is characterized by a large amount of pollen grains and nectar. The female phase, in turn, lasts three days and has only nectar stored in the base of corolla. The floral tubes had $37.7 \pm 2.7 \mathrm{~mm}$ in length $(\mathrm{n}=15)$ and corolla diameter of $9.1 \pm 0.9 \mathrm{~mm}(\mathrm{n}=15)$. At the beginning of the anthesis, the anthers are positioned at the entrance of corolla. After the pollen dispersion, the anthers become dry and retract, allowing the stretching of the style that is located behind the stamens. In this way, the stigma is exposed in a superior position to the anthers. At this phase, the stigmatic surface is expanded and there is a slight color change from green to whitish.

From the 424 flowers sampled in one day, 209 were in male phase and 215 flowers in female phase. The nectar volume was $36.5 \pm 20.1 \mathrm{~mL}$ ( $\mathrm{n}=$ $20)$ and sugar concentration was $25.5 \pm 5.2 \%(\mathrm{n}=$ 20). The energetic offer per flower was estimated in $40.8 \mathrm{cal} \pm 4.2(\mathrm{n}=20)$. During the flowering peak, the $S$. elatior population had 594 open flowers that could offer around $23 \mathrm{Kcal}$ (Fig. 1), with a capacity

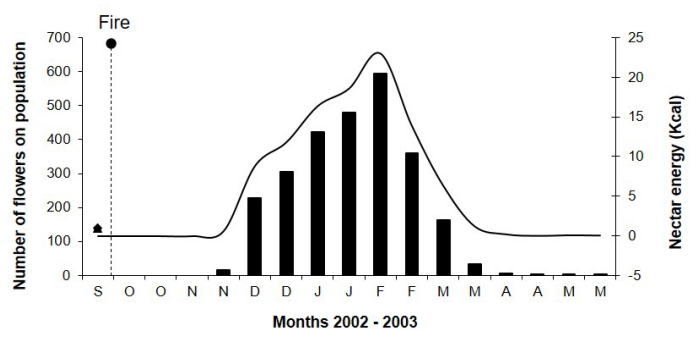

Figure 1 - Floral phenology and energy of nectar of a Sinningia elatior population sampled biweekly after the fire that occurred at the end of September 2002 at the Ecological Reserve 'Clube de Caça e Pesca Itororó de Uberlândia'. Bars represent the number of flowers and the line represents the energy of nectar in Kcal. to feed approximately two to four hummingbirds per day depending on the energy requirements of each species.

Sinningia elatior is self-compatible with spontaneous self-pollination, but apomixis was not observed (Tab. 1). The pollen viability was probably high since approximately $99 \%$ of pollen grains from the ten flowers were stained on aceticcarmine. The stamens are exserted in male phase (Fig. 2a) and liberate all pollen grains at once. The stigma was physically receptive on the third day of flower duration when it was positioned out of the floral tube and at the height of anthers (Fig. 2b).

Results from the five pollination treatments are displayed in Table 1. Fruit set success after hand self-pollination and cross-pollination did not differ significantly (Chi-square $=2.12, \mathrm{df}=1, \mathrm{P}=1.5 \mathrm{E}-$ 01). Emasculated flowers produced no fruit (Tab. 1). Fruit set in bagged flowers was significantly lower when compared to open-pollinated flowers: hand self-pollination $($ Chi-square $=38.21, \mathrm{df}=1$, $\mathrm{P}=6.3 \mathrm{E}-10)$ and cross-pollination (Chi-square $=$ 36.29, df = 1, $\mathrm{P}=1.7 \mathrm{E}-09$ ).

During the study period a total of nine hummingbird species (Tab. 2) distributed in nine genera were observed: Amazilia fimbriata (Gmelin), Anthracothorax nigricollis (Vieillot), Chlorostilbon lucidus (Shaw), Colibri serrirostris (Vieillot), Eupetomena macroura (Gmelin) (Fig. 2c), Heliomaster squamosus (Temminck), Hylocharis chrysura (Shaw), Polytmus guainumbi (Pallas) (Trochilinae) and Phaethornis pretrei (Lesson \& Delattre) (Fig. 2d) (Phaethornithinae). Eupetomena macroura and C. serrirostris were the most frequent hummingbirds on flowers and displayed an aggressive behavior against the other species. The species $H$. chrysura and $P$. pretrei visited flowers from $S$. elatior individuals located at the edge of an island of flooded gallery forest whereas the other hummingbird species were observed in open areas of palm swamp. All hummingbirds acted as pollinators of $S$. elatior contacting anthers and stigma.

Sixteen insect species were recorded on S. elatior flowers collecting pollen and nectar (Tab. 2). The beetle Lagria villosa (Fabricius) (Tenebrionidae) was observed eating the parts of both corolla and anthers. The other insect species visited the flowers mainly during the male phase when both pollen and nectar were available. Only small-sized insects such as Camponotus crassus Mayr (Formicidae), Polybia occidentalis (Olivier) (Vespidae), Augochlorella ephyra Schrottky and 

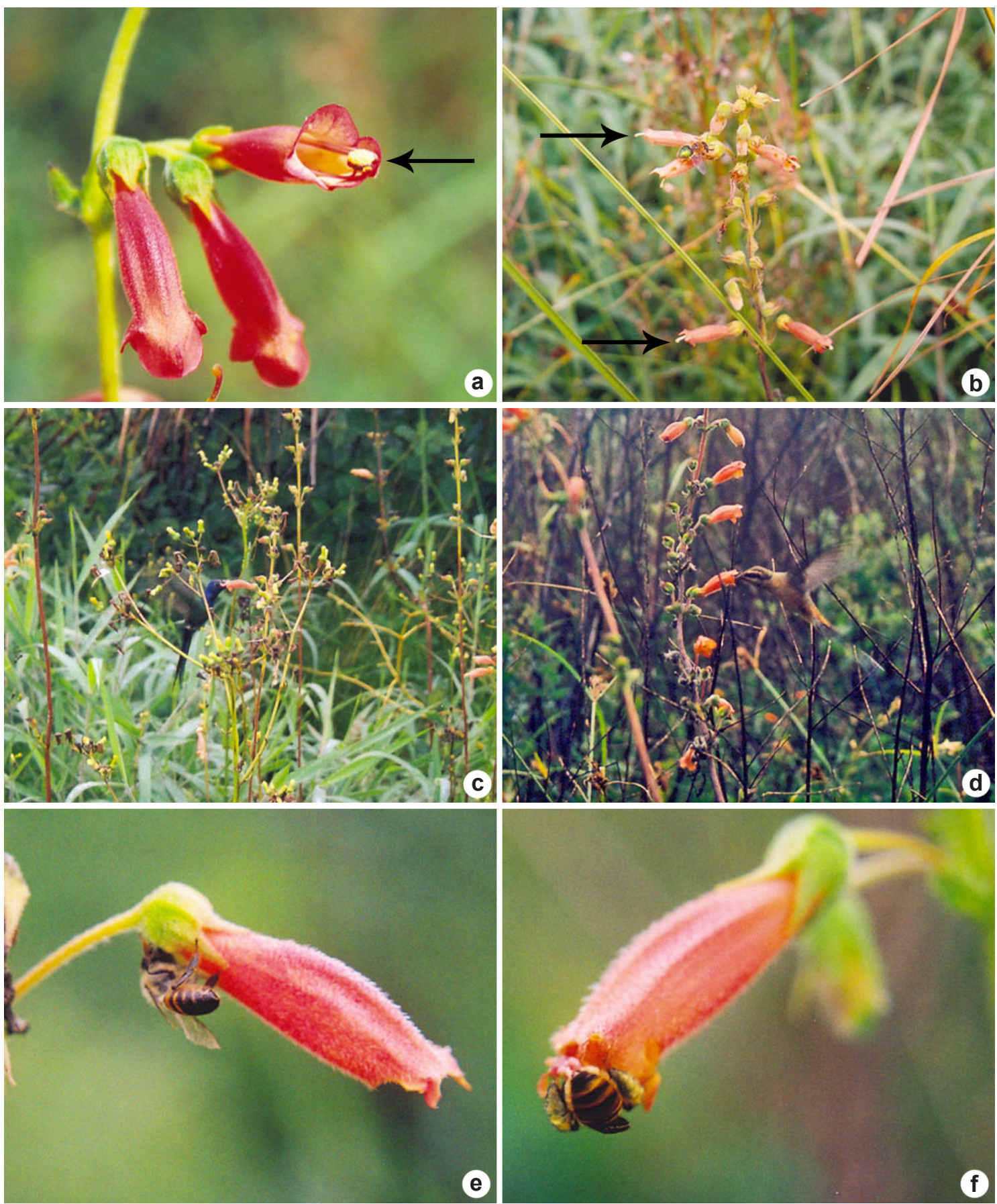

Figure 2 - a-f. Flower characteristics and floral visitors of Sinningia elatior - a. stamens in male phase indicated by a black arrow; b. stigmas in female phase indicated by black arrows and a female of Oxaea flavescens drinking nectar from the base of corolla; c. Eupetomena macroura visiting a flower; d. Phaethornis pretrei visiting a flower; e. Apis mellifera robbing nectar from the base of corolla; f. a female of Exomalopsis fulvofasciata robbing pollen. 
Table 1 - Results from the pollination treatments of Sinningia elatior (Gesneriaceae) in a palm swamp area at Ecological Reserve 'Clube de Caça e Pesca Itororó de Uberlândia', southeastern Brazil. Percentages followed by distinct letters differed significantly when using Chi-square test at $\mathrm{P}<0.05$ with Bonferroni correction $(\mathrm{P}=0.0083)$.

\begin{tabular}{lccc}
\hline Treatments & Pollinated flowers (n) & Fruits set (n) & Fruit set success (\%) \\
\hline Hand self-pollination & 24 & 19 & $79.16^{\mathrm{a}}$ \\
Spontaneous self-pollination & 43 & 15 & $34.88^{\mathrm{b}}$ \\
Emasculation without pollination & 19 & 0 & $0^{\mathrm{c}}$ \\
Cross-pollination & 39 & 35 & $89.74^{\mathrm{a}}$ \\
Natural pollination & 70 & 65 & $92.85^{\mathrm{a}}$ \\
\hline
\end{tabular}

Table 2 - Floral visitors of Sinningia elatior in a palm swamp area at Ecological Reserve 'Clube de Caça e Pesca Itororó de Uberlândia', southeastern Brazil. Floral visitors' frequency: Rare $<4$ visits; Occasional $=4$ to 10 visits; Frequent $>11$ visits.

\begin{tabular}{|c|c|c|c|}
\hline Orders & Families & Species & Frequency \\
\hline \multirow[t]{9}{*}{ Apodiformes } & Trochilidae & Amazilia fimbriata (Gmelin) & Occasional \\
\hline & & Anthracothorax nigricollis (Vieillot) & Rare \\
\hline & & Chlorostilbon lucidus (Shaw) & Occasional \\
\hline & & Colibri serrirostris (Vieillot) & Frequent \\
\hline & & Eupetomena macroura (Gmelin) & Frequent \\
\hline & & Heliomaster squamosus (Temminck) & Rare \\
\hline & & Hylocharis chrysura (Shaw) & Rare \\
\hline & & Phaethornis pretrei (Lesson \& Delattre) & Occasional \\
\hline & & Polytmus guainumbi (Pallas) & Rare \\
\hline Coleoptera & Tenebrionidae & Lagria villosa (Fabricius) & Rare \\
\hline \multirow[t]{15}{*}{ Hymenoptera } & Andrenidae & Oxaea flavescens Klug & Occasional \\
\hline & Apidae & Apis mellifera Linnaeus & Frequent \\
\hline & & Bombus morio (Swederus) & Occasional \\
\hline & & Exomalopsis fulvofasciata Smith & Frequent \\
\hline & & Paratrigona lineata (Lepeletier) & Occasional \\
\hline & & Trigona hyalinata (Lepeletier) & Occasional \\
\hline & & Trigona spinipes Fabricius & Frequent \\
\hline & & Xylocopa hirsutissima Maidl & Rare \\
\hline & & Xylocopa nogueirai Hurd \& Moure & Frequent \\
\hline & Halictidae & Augochlorella ephyra Schrottky & Rare \\
\hline & & Dialictus sp. & Rare \\
\hline & & Pseudaugochlora sp. & Occasional \\
\hline & Formicidae & Camponotus crassus Mayr & Occasional \\
\hline & Vespidae & Polybia occidentalis (Olivier) & Occasional \\
\hline & & Synoeca surinama Linnaeus & Rare \\
\hline
\end{tabular}


Dialictus sp. (Halictidae) entered the flowers to collect nectar without contacting the stigma. All the other species were observed perforating the base of corolla to rob the accumulated nectar. The bees Apis mellifera Linnaeus (Fig. 2e) and Paratrigona lineata (Lepeletier) used the holes in the corolla perforated by other species to collect nectar. Apis mellifera, Exomalopsis fulvofasciata Smith (Fig. 2f), Trigona hyalinata (Lepeletier), $T$. spinipes Fabricius and Xylocopa nogueirai Hurd $\&$ Moure (Apidae) collected pollen grains without contacting the stigmatic surface. Therefore, none of the insects recorded on S. elatior flowers acted as effective pollinators.

\section{Discussion}

The annual blooming of S. elatior, differently from Vellozia sincorana L.B.Sm. \& Ayensu (Velloziaceae) (see Conceição \& Orr 2012) is not fire-dependent but likewise many other Cerrado plant species is characterized by an intense massflowering after the fire (Haddad \& Valio 1993; Hoffmann 1999; Franceschinelli \& Bawa 2005). In the same study site, Silva (2003) carried out a study on the reproductive phenology of the plant community in a palm swamp area that was not affected by fire from 1999 to 2002 . The author recorded only a few individuals of $S$. elatior that flowered from September to December 2000 and in October 2001.

The passage of fire can induce flowering due to multiple factors/triggers. For example, the enhancing temperature caused by the presence of ethylene or acetylene as a smoke component. Moreover, the ashes, resulting in an increase in nutrients that can be incorporated into the soil. The light, through an increase of irradiance caused by burning of covering neighboring plants and darkness, after burning of leaves (light-sensors) producing a corresponding dark period until the growth of new leaves. Finally, water deficit, through the reduction of soil moisture caused by an increase in temperature (Haddad \& Valio 1993; Araújo et al. 2013).

The extended flowering pattern observed in $S$. elatior is in part a consequence of the longevity of each flower. The flower longevity can contribute to the plant display to attract pollinators (Stiles 1981). The long duration of flowers, characterized by the switch in male and female phases, known as protandry, is an important factor that can result in a significant increase in cross-pollination success (Rathcke 2003). Protandry is considered a strategy to avoid self-pollination at the same time that can promote cross-pollination (Lloyd $\&$ Webb 1986). The spontaneous self-pollination observed in S. elatior, nevertheless, would ensure the seed set even if pollinators are scarce or absent. The capacity to self-pollinate is also in contrast to many hummingbird plants from the Cerrado, especially from the open areas, which were found to be predominantly self-incompatible (Ferreira et al. 2016).

The massive post-fire flowering of S. elatior produced a pulse in the energy availability of such magnitude that its population alone attracted nine hummingbird species to the study area. This value was almost twice the number of hummingbird species that were recorded in a community composed of ten plant species in an island of flooded gallery Forest in the same area (Araújo et al. 2011a) and from the neighboring savanna vegetation in the same reserve (with seven species, Maruyama et al. 2013). Moreover, the estimated amount of hummingbirds that the $S$. elatior population was able to sustain during its flowering peak was also superior when compared to the capacity estimated for the whole plant community sampled in the island of flooded gallery Forest, which had enough only for a single bird (Araújo et al. 2011a). As the nectar was measured only in the first day, and the population had flowers in different phases, the available energy may be under or overestimated.

Because studies such as ours must usually take advantage of fortuitous fire in natural vegetation, the consequences to a given plant population as well as to the whole associated community are poorly known. To the best of our knowledge, there are no records whether such flowerings providing special offers could impact negatively other plant species since the pollinators could have been displaced from other areas where they would pollinate other species. However, some studies described an increase in pollination of plants that bloomed nearby the so called magnetic species due to the augment of pollinators' availability in the area (Thomson 1978; Johnson et al. 2003).

An intense mass-flowering may be an opportunity to increase the outcrossing rate because when plant and flower densities within population are high, pollinator activity among plants increases and several plants are visited, which enhances pollen exchange among them (Farris \& Mitton 1984; Burdon et al. 1988; Van Treuren et al. 1993; Franceschinelli \& Bawa 2005). On the other 
hand, massive flowerings can attract territorial hummingbirds that may constrain pollen flow to a single patch of nearby flowers due to their forage behavior reducing outcrossing rates among distant plant individuals (Justino et al. 2012; Maruyama et al. 2016). For several plant species, fitness may be enhanced when pollinators are neither too faithful nor too fickle (McDade \& Weeks 2004). This situation in which the increase in the number of flowers represents a conflict between attracting many pollinators versus concentrating the flow of pollen among few individuals is known as 'plant dilemma' (Barônio et al. 2016).

Sinningia elatior is a trochilophilous species, but among hummingbirds there are many morphological differences such as length and shape of the beak. Those differences may limit their access to the nectar in certain types of flowers as those of Costus spiralis (Jacq.) Roscoe (Costaceae) whose flowers limit the access of nectar only to better-fitted hummingbirds with curved, long beak such as Phaethornis pretrei (Araújo \& Oliveira 2007). In this way S. elatior is more generalist than other trochilophilous species as the corolla of its flowers does not represent a barrier to any of the hummingbird species in the area. In addition, the high nectar volume secreted by the flowers represents an important feature to attract a high diversity of hummingbirds. The nectar volume produced in $S$. elatior flowers was higher than that secreted by other trochilophilous Sinningia species (Sazima et al. 1996; SanMartin-Gajardo \& Sazima 2005). In this context, SanMartin-Gajardo \& Sazima (2005) recorded a higher number of visits by hummingbirds in Vanhouttea species that secrete a larger quantity of nectar when compared to Sinningia species that produced a smaller volume of that resource. Also, visitation frequency of hummingbirds in open areas of Cerrado is determined by population-wide nectar offer of plants (Maruyama et al. 2013). Two hummingbird species that displayed territorial behavior, E. macroura and C. serrirostris, were the most frequent pollinators of $S$. elatior. In the same study site, E. macroura was rarely recorded in a putative trochilophilous plant community but it became one of the most frequent hummingbird species during the massive post-fire flowering of $S$. elatior (Araújo et al. 2011a). The high frequency of territorial hummingbirds observed herein may be related to the distribution of $S$. elatior individuals in the area since the vast majority was located in open areas of palm swamp. SanMartin-Gajardo \& Sazima (2005) pointed out that Sinningia cochlearis
(Hook.) Chautems, a species that occur in open areas, was pollinated exclusively by Trochilinae whereas $S$. gigantifolia Chautems, predominantly found in forested areas, was pollinated only by Phaethornithinae. Some trochilophilous species can be specialized in receiving visits of territorial hummingbirds like Gaylussacia brasiliensis (Spreng.) Meisn. (Ericaceae) (Araújo et al. 2011b) whereas other plants such as Costus spiralis are more visited by traplining species (Araújo \& Oliveira 2007). From the plant species perspective, territorial hummingbirds concentrate pollen within a single population while trapliners are able to disperse pollen grains to longer distances (Araújo \& Oliveira 2007; Maruyama et al. 2016). It is likely that $S$. elatior is not specialized to any foraging strategy of hummingbirds, and benefits from the maximum number of visits in periods marked by a low flower production in the community.

A high number of thief/robber insects were recorded on S. elatior flowers. Even though this plant species is characterized as ornitophilous, this feature does not impede the occasional visits of different floral visitors, as observed by Camargo et al. (2011) on flowers of Seemannia sylvatica (Kunth) Baill. (Gesneriaceae). Likewise, flowers of Paliavana tenuiflora Mansf. were visited primarily by the bumblebee Bombus brevivillus Franklin (Apidae) while the hummingbird Phaethornis pretrei acted as an occasional pollinator due to its behavior on flowers and low visit frequency (Ferreira \& Viana 2010). All insect species observed on S. elatior flowers were illegitimate and the pollen/nectar robbery behavior of those species together might represent a detrimental effect on the hummingbird species that acted as pollinators. Additionally, the floral resources larceny may impose a high energy expenditure to the plant individual since the resources must be replaced and flowers become less attractive, reducing the visits performed by legitimate pollinators (Navarro 1999). Nevertheless, if pollinators respond to this decrease of floral reward by traveling to more distant flowers, therefore plant fitness may be enhanced through increased cross-pollination rates (Maloof 2001; McDade \& Weeks 2004).

The effect caused by this massive post-fire flowering on pollinators can be compared to a sales promotion in a store. Generally, a good offer attracts many buyers who might be just passing nearby and decide to stop and seize the opportunity. These special nectar offers in Cerrado are rare and unpredictable. Although fire is a common event in 
this biome, it does not always coincide with the habitats that specific plants occur, nor with their flowering period. Therefore, these offers, such as sales promotion in stores, also rare and somewhat unexpected, are available only while stocks last.

In conclusion, our study reports on a massive flowering of the hummingbird-pollinated S. elatior following the disturbance caused by fire. The flowering dynamics of Cerrado species is very diverse and the fire regime acts shaping the massive flowering mosaics, producing temporary special offers of floral resources that affect not only the foraging dynamics of pollinators but possibly also the crossing patterns of the plant species.

\section{Acknowledgements}

The authors thank Pietro Maruyama (Unicamp) and two anonymous referees for their constructive comments and suggestions to improve the quality of our manuscript. We also are grateful to Gabriel Melo (UFPR) (bee identifications), Renata Pacheco (UFU) (Camponotus), and Sidnei Mateus (FFCLRP/USP) (wasps) for identifying some of the insect species collected on flowers.

\section{References}

Appezzato-da-Glória B (2003) Morfologia de sistemas subterrâneos: histórico e evolução do conhecimento no Brasil. Ed. Alexandre Sene Pinto, Ribeirão Preto. 80p.

Appolinario V \& Schiavini I (2002) Levantamento fitossociológico de espécies arbóreas de Cerrado (stricto sensu) em Uberlândia - Minas Gerais. Boletim do Herbário Ezechias Paulo Heringer 10: 57-75.

Araújo AO \& Chautems A (2015) Sinningia in Lista de Espécies da Flora do Brasil. Instituto de Pesquisas Jardim Botânico do Rio de Janeiro. Available at $<$ http://floradobrasil.jbrj.gov.br/jabot/floradobrasil/ FB7898>. Access on 10 July 2017.

Araújo AO, Chautems A \& Ferreira GE (2015) Gesneriaceae. In: Flora do Brasil 2020 em construção. Instituto de Pesquisas Jardim Botânico do Rio de Janeiro. Available at $<$ http://floradobrasil. jbrj.gov.br/jabot/floradobrasil/FB119>. Access on 10 July 2017.

Araújo FP \& Oliveira PE (2007) Biologia floral de Costus spiralis (Jacq.) Roscoe (Costaceae) e mecanismos para evitar a autopolinização. Revista Brasileira de Botânica 30: 61-70.

Araújo FP, Barbosa AAA \& Oliveira PE (2011a) Floral resources and hummingbirds on an island of flooded forest in Central Brazil. Flora 206: 827-835.

Araújo FP, Farias YEF \& Oliveira PE (2011b) Biologia floral e visitantes de Gaylussacia brasiliensis (Spr.)
Meissner (Ericaceae) - uma espécie com anteras poricidas polinizada por beija-flores. Acta Botanica Brasilica 25: 387-394.

Araújo GM, Amaral AF, Bruna EM \& Vasconcelos HL (2013) Fire drives the reproductive responses of herbaceous plants in a Neotropical swamp. Plant Ecology 214: 1479-1484.

Barônio GJ, Maciel AA, Oliveira AC, Kobal ROAC, Meireles DAL, Brito VLG \& Rech AR (2016) Plantas, polinizadores e algumas articulações da biologia da polinização com a teoria ecológica. Rodriguésia 67: 275-293.

Burdon JJ, Jarosz AM \& Brown AHD (1988) Temporal patterns of reproduction and outcrossing in weedy populations of Echium plantagineum. Biological Journal of Linnaean Society 34: 81-92.

Camargo E, Rodrigues LC \& Araújo AC (2011) Pollination biology and reproduction of Seemannia sylvatica (Kunth) Hanstein (Gesneriaceae) in the Serra da Bodoquena National Park, Mato Grosso do Sul. Biota Neotropica 11: 125-130.

Carpenter FL (1983) Pollination energetics in avian communities: simple concepts and complex realities. In: Jones EC \& Little JR (eds.) Handbook of experimental pollination biology. Scientific and Academic Editions, Van Wostrand. Pp. 215-234.

Chautems A (2003) Gesneriaceae. In: Wanderley MGL, Shepherd GJ, Giulietti AM \& Melhem TS (coords.) Flora fanerogâmica do estado de São Paulo. Instituto de Botânica, São Paulo. Vol. 3, pp. 75-103.

Conceição AA \& Orr BJ (2012) Post-fire flowering and fruiting in Vellozia sincorana, a caulescent rosette plant endemic to Northeast Brazil. Acta Botanica Brasilica 26: 94-100.

Conceição AA, Alencar TG, Souza JM, Moura AD \& Silva GA (2013) Massive post-fire flowering events in a tropical mountain region of Brazil: high episodic supply of floral resources. Acta Botanica Brasilica 27: 847-850.

Coutinho LM (1977) Aspectos ecológicos do fogo no Cerrado. 2. As queimadas e a dispersão de sementes de algumas espécies anemocóricas do estrato herbáceo-subarbustivo. Boletim de Botânica da Universidade de São Paulo 5: 57-64.

Dafni A, Pacini E \& Nepi M (2005) Pollen and stigma biology. In: Dafni A, Kevan P \& Husband BC (eds.) Practical pollination biology. Enviroquest, Ontario. Pp. 83-146.

Farris MA \& Mitton JB (1984) Population density, outcrossing rate, and heterozygote superiority in ponderosa pine. Evolution 38: 1151-1154.

Ferreira C, Maruyama PK \& Oliveira PE (2016) Convergence beyond flower morphology? Reproductive biology of hummingbird-pollinated plants in the Brazilian Cerrado. Plant Biology 18: 316-324.

Ferreira PA \& Viana BF (2010) Pollination biology of Paliavana tenuiflora (Gesneriaceae: Sinningeae) 
in northeastern Brazil. Acta Botanica Brasilica 24: 972-977.

Fidalgo O \& Bononi VLR (1984) Técnicas de coleta, preservação e herbarização de material botânico. Instituto de Botânica/Secretaria do Meio Ambiente, São Paulo. 62p.

Franceschinelli EV \& Bawa KS (2005) The post-fire effects on the outcrossing rate of a Brazilian savannah shrub, Helicteres sacarolha A.St.-Hil. Revista Brasileira de Botânica 28: 163-170.

Galetto L \& Bernardello G (2005) Nectar. In: Dafni A, Kevan P \& Husband BC (eds.) Practical pollination biology. Enviroquest, Ontario. Pp. 261-313.

Gonçalves CN, Mesquita FW, Lima NRG, Coslope LA \& Lintomen BS (2011) Recorrência dos incêndios e fitossociologia da vegetação em áreas com diferentes regimes de queima no Parque Nacional da Chapada Diamantina. Biodiversidade Brasileira 1: 161-179.

Grantsau R (1989) Os beija-flores do Brasil. Expressão e Cultura, Rio de Janeiro. 233p.

Haddad CRB \& Valio IMF (1993) Effect of fire on flowering of Lantana montevidensis Briq. Journal of Plant Physiology 141: 704-707.

Heringer I \& Jacques AV (2001) Adaptação das plantas ao fogo: enfoque na transição floresta-campo. Ciência Rural 31: 1085-1090.

Hoffmann WA (1999) Fire and population dynamic of woody plants in a neotropical savanna: matrix model projections. Ecology 80: 1354-1369.

Johnson SD, Peter CI, Nilsson A \& Agren J (2003) Pollination success in a deceptive orchid is enhanced by co-occuring rewarding magnet plants. Ecology 84: 2919-2927.

Justino DG, Maruyama PK \& Oliveira PE (2012) Floral resource availability and hummingbird territorial behaviour on Neotropical savana shrub. Journal of Ornithology 153: 189-197.

Kearns CA \& Inouye DW (1993) Techniques for pollination biologists. University Press of Colorado, Niwot. 583p.

Lima SC, Rosa R \& Feltran-Filho A (1989) Mapeamento do uso do solo no município de Uberlândia-MG, através de imagens TM/LANDSAT. Sociedade \& Natureza 1: 127-145.

Lloyd DG \& Webb CJ (1986) The avoidance of interference between the presentation of pollen and stigmas in angiosperms - I Dichogamy. New Zealand Journal of Botany 24: 135-162.

Maloof JE (2001) The effects of a bumble bee nectar robber on plant reproductive success and pollinator behavior. American Journal of Botany 88: 19601965.

Maruyama PK, Oliveira GM, Ferreira C, Dalsgaard B \& Oliveira PE (2013) Pollination syndromes ignored: importance of non-ornithophilous flowers to Neotropical savanna hummingbirds. Naturwissenschaften 100: 1061-1068.
Maruyama PK, Justino DG \& Oliveira PE (2016) Does intraspecific behavioural variation of pollinator species influence pollination? A quantitative study with hummingbirds and a Neotropical shrub. Plant Biology 18: 913-919.

McDade LA \& Weeks JA (2004) Nectar in hummingbirdpollinated Neotropical Plants II: interactions with flower visitors. Biotropica 36: 216-230.

Miranda HS \& Sato MN (2005) Efeitos do fogo sobre a vegetação lenhosa do cerrado. In: Scarlot A, SouzaSilva JC \& Felfili JM (eds.) Cerrado: ecologia, biodiversidade e conservação. Ministério do Meio Ambiente, Brasília. Pp. 95-105.

Miranda HS, Bustamante MMC \& Miranda AC (2002) The Fire Factor. In: Oliveira PS \& Marquis RJ (eds.) The Cerrados of Brazil - ecology and natural history of a Neotropical Savanna. Columbia University Press, New York. Pp. 51-68.

Mistry J (1998) Fire in the Cerrado (savannas) of Brazil: an ecological review. Progress in Physical Geography 22: 425-448.

Navarro L (1999) Pollination ecology and effect of nectar removal in Macleania bullata (Ericaceae). Biotropica 31: 618-625.

Neves SPS \& Conceição AA (2010) Campo rupestre recém-queimado na Chapada Diamantina, Bahia, Brasil: plantas de rebrota e sementes, com espécies endêmicas na rocha. Acta Botanica Brasilica 24: 697-707.

Newstrom LE, Frankie GW \& Baker HG (1994) A new classification for plant phenology based on flowering patterns in lowland tropical rain forest trees at $\mathrm{La}$ Selva, Costa Rica. Biotropica 26: 141-159.

Perret M, Chautems A, Spichiger R, Peixoto M \& Savolainen V (2001) Nectar sugar composition in relation to pollination syndromes in Sinningieae (Gesneriaceae). Annals of Botany 87: 267-273.

Perret M, Chautems A, Spichiger R, Kite G \& Savolainen V (2003) Systematics and evolution of tribe Sinningieae (Gesneriaceae): evidence from phylogenetic analyses of six plastid DNA regions and nuclear ncpGS. American Journal of Botany 90: 445-460.

Radford AE, Dickson WC, Massey JR \& Bell CR (1974) Vascular plant systematics. Harper \& Row, New York. 891p.

Rathcke BJ (2003) Floral longevity and reproductive assurance: seasonal patterns and an experimental test with Kalmia latifolia (Ericaceae). American Journal of Botany 90: 1328-1332.

Rosa R, Lima SC \& Assunção WL (1991) Abordagem preliminar das condições climáticas de Uberlândia (MG). Sociedade \& Natureza 3: 91-108.

SanMartin-Gajardo I \& Sazima M (2005) Espécies de Vanhouttea Lem. e Sinningia Nees (Gesneriaceae) polinizadas por beija-flores: interações relacionadas ao hábitat da planta e ao néctar. Revista Brasileira de Botânica 28: 441-450. 
Sazima I, Buzato S \& Sazima M (1996) An assemblage of hummingbird-pollinated flowers in a montane forest in southeastern Brazil. Botanica Acta 109: 149-160.

Sherman RE, Fahey TJ, Martin PH \& Battles JJ (2012) Patterns of growth, recruitment, mortality and biomass across an altitudinal gradient in a neotropical montane forest, Dominican Republic. Journal of Tropical Ecology 28: 483-495.

Silva MR (2003) Florística, fenologia e sexualidade de espécies de vereda em Uberlândia/MG. B.Sc. Thesis. Universidade Federal de Uberlândia, Uberlândia. 42p.

Stiles FG (1981) Geographical aspects of bird-flower coevolution, with particular reference to Central America. Annual of the Missouri Botanical Garden 68: 323-351.
Thomson JD (1978) Effects of stand composition on insect visitation in two-species mixtures of Hieractioum. American Midland Naturalist 100: 431-440.

Van Treuren R, Bijlsma R, Ouborg NJ \& Van Delden W (1993) The effects of population size and plant density on outcrossing rates in locally endangered Salvia pratensis. Evolution 47: 1094-1104.

Weber A (2004) Gesneriaceae. In: Kubitzki K (ed.) The families and genera of vascular plants. Dicotyledons, Lamiales (except Acanthaceae incl. Avicennieae), Vol. VII. Springer, Berlin. Pp. 63-158.

Weber A, Clark JL \& Möller M (2013) A new formal classification of Gesneriaceae. Selbyana 31: 68-94. This is an open-access article distributed under the terms of the Creative Commons Attribution License. 